Dr. H. C. Smith

Dr. H. C. SMith, senior principal scientific officer in the Plant Diseases Division, has been appointed director of the Department's Crop Research Division. Dr. Smith was educated at Massey Agricultural College, where he gained an M.Agr.Sc. degree, specializing in plant pathology. In 1951 he was awarded a National research scholarship at the University of Cambridge. There he undertook research work for his Ph.D. on Phytophthora. On completing his Ph.D. degree in 1953 , he returned to New Zealand and was appointed mycologist at the Plant Diseases Division sub-station at Lincoln. In $1960 \mathrm{Dr}$. Smith was awarded a Canadian National research fellowship, which he held at the Canadian National Research Council's Plant Research Institute at Ottawa, where he studied virus diseases of grasses and cereals, and in particular barley yellow dwarf virus which he had already been investigating in New Zealand. His work on this disease has led to the development of effective control measures of great economic significance to barley and wheat growers in New Zealand.

Dr. J. M. Hoy

DR. J. M. Hox has been appointed director of the Entomology Division, Nelson, in succession to the late
Dr. W. Cottier. Dr. Hoy was educated at Otago Boys' and King's High Schools, Dunedin, and at Lincoln College, where he gained B.Agr.Sc. in 1942. In 1943 he became entomologist in charge of malarial control for the Royal New Zealand Air Force in the south-west Pacific area. In this capacity he spent a year in the forward Pacific war area. On his return from overseas in 1945 he joined the Entomology Division of the Department of Scientific and Industrial Research as assistant entomologist, Nelson, where he was concerned with the systematic investigation of the larvæ of grass grubs and the possible utilization of nematodes to control pasture insects. In $1953 \mathrm{Dr}$. Hoy was appointed officer-in-charge of Fntomology Division's sub-station at Palmerston North. This unit made an intensive investigation of manuka blight, and Dr. Hoy was responsible for the discovery that the causal insect, Eriococcus, was Australian in origin. For his work on scale insects he was awarded a D.Sc. by Lincoln College early in 1964. In March $1963 \mathrm{Dr}$. Hoy joined the headquarters staff of Entomology Division at Nelson to lead the research team concerned with present work on the control of grass grub and subterranean grass caterpillar. Dr. Hoy is immediato past-president of the New Zealand Entomological Society and is vice-president of the Nelson Branch of the Royal Socinty of Now Zealand.

\title{
ORGANIZATION AND ADMINISTRATION OF INDIAN SCIENCE
}

\begin{abstract}
IN successive annual reports on the Commonwealth Scholarship and Fellowship Plan the Commonwealth Education Liaison Committee has expressed concern at the reluctance of some scholars to return home on com. pletion of their tenure. This was discussed at some length in the third report, and the difficulty appears to have become more acute during the past year. It is appreciated that the temptation to remain in Britain, for example, may be considerable when the scholar can see no immediate prospect of obtaining employment in his home country at the level he regards as suitable to his qualifications, or when opportunities for further research are severely limited at home.
\end{abstract}

Some light is thrown on this reluctance to return home, so far as India is concerned, by a memorandum on Indian Scientific Policy submitted by the Institute of Political and Social Studies to the Review Committee of the Council of Scientific and Industrial Research on National Research Laboratories, and published in Minerva (11, 519 ; Summer, 1964). It is also illuminated by the comments which Dr. K. A. C. Mendelssohn made in a broadcast talk "Science in India". discussing his visit to India in 1963, which was published in The Listener for September 24 $(72,457 ; 1964)$.

The main submission of the Institute of Political and Social Studies is that the Review Committee, to which its memorandum is addressed, should concentrate on creating a suitable climate for serious scientific research in the national research laboratories. It is considered in the memorandum that the previous Minister for Scientific Research and Cultural Affairs was at least partly aware of the problem, and it quotes his references, when addressing a recent conference of scientists and educationalists, to the lack of an atmosphere of activity sustained by critical appreciation and the existence of a bureaucracy in the scientific field, tending to a false sense of prestige due to status and office. These criticisms fully confirm Dr. Mendelssohn's observations. In general, the authors of the memorandum believe that the organization of research has proliferated too widely and rapidly, with excessive attention to buildings and equipment, etc., compared with training and expanding the initial nucleus of research staff. There are now 27 national laboratories and other allied research institutions, housed and substantially equipped and with further facilities in prospect; in spite of this, the memorandum asks the fundamental questions whether a suitable research leadership has emerged in each of these institutions, and whether a climate has developed which spurs the research worker to do his job well. The whole implication of the memorandum is that neither question can be answered in the affirmative without hesitation or reservations.

The Institute of Political and Social Studies, however, goes further and directs attention to specific points. It questions whether the laboratories are recruiting scientific workers, particularly in the senior grades, who combine aptitude for research with basic competence in the particular field. Enquiry here could go far to explain the reluctance of Indian scholars and Fellows to return from abroad. The mere fact that the memorandum suggests that it would be worth while to consider setting up a highlevel selection body for recruiting scientists on the pattern of the Union Public Service Commission indicates that all is not well with present methods of recruitment. It also directs attention to the vital importance of ensuring that the research worker can rely on obtaining guidance and on critical appreciation of his efforts. It asks key questions about direction of the laboratory, both as regards the formu lation and study of problems and the publication of results.

The questions about relations with industry, about the establishment of regional research laboratories, about duplication at the national level, are both searching and constructive. The memorandum gives firm support to the younger workers; like Dr. Mendelssohn, the Institute has evidently formed the opinion that the younger men do not always receive a fair chance and that conditions are not conducive to serious research by many competent scientists. The core of its criticism is, in fact, that the direction of many of the laboratories is often defective, if not incompetent, and that this position is at least partly due to the form of organization under the Council of Scientific and Industrial Research. 
Perhaps the most encouraging feature of the memorandum is the evidence it provides that the Institute of Political and Social Studies has clear ideas as to what is needed, in respect of the conditions on which effective research depends, of the organization of research, and of the qualities required in its direction. Dr. Mendelssohn's broadcast talk supplies evidence that there are other Indian sources also competent to give the Review Committee all the guidance it should need as to the organization of the National Research Laboratories. A.t the outset, however, he makes it only too apparent that the causes run deep and that there is widespread frustration and discontent in universities as well as in Government research laboratories, largely but not wholly due to the effect of the 20 per cent cut in their budgets imposed as an emergency measure in 1963 . Since the director could not dismiss his staff and their salaries had to be paid, this involved a reduction of 60-70 per cent in running expenses.

Dr. Mendelssohn picks out the quality of scientific publication, and the reluctance of Indian scientists to return to India after training in the West, as evidence that all is not well with science and technology in India. His observations satisfied him that there was justification in some of the reasons given for this reluctance-in the lack of appreciation, insufficient means for research, difficulties in obtaining equipment, pettiness and jealousy among colleagues. It seems only too clear that Dr. Dedijer's plea for a clearer understanding of science and its implications and for the formulation of scientific policy, addressed more particularly to the emerging nations, applies no less to India. Too many of her politicians, as Dr. Mendelssohn recognizes, are not science-minded, and the trouble starts in the universities, modelled on Western institutions of the pre-scientific era.
While it is true that the whole purpose of the Commonwealth Scholarship and Fellowship Plan will be defeated if many of the Scholars and Fellows do not return to their own country when tenure of their scholarship and fellowship expires, it must not be forgotten that this is largely a matter for the country which sends the scholars and Fellows. Fortunately, as Dr. Mendelssohn shows, there are hopeful signs. India, he recognizes, has scientists who are second to none. $\mathrm{H}_{e}$ is impressed by her reserve of capable brains and by the younger generation of scientists whose love for their subject is matched by their capacity for hard work, and often by their competence. Moreover, there are, here and there, as at the Tata Institute in Bombay and the Atomic Energy Research Laboratories at Trombay, those who have the strength of character to oppose the Government, and he does not despair of the real impetus coming, as it must, from India itself.

What is needed is to create the conditions in which the young generation of Indian scientists can develop their talents and work for their country, and what Indian professors and directors of research need is the art of talking to their own Government. These are the two key conditions which will determine the readiness of Indian scholars abroad to return to their country. This should be remembered both in discussing the future of the Commonwealth Scholarship and Fellowship Plan, and in assessing the extent and character of the technical assistance given to India. With sympathy and insight much could be done indirectly, rather than by direct action, to help Indian politicians to understand the situation and to appreciate the nature of the action required, if not merely India's science but her general economic and social development are to proceed on the scale and at the rate which has been planned.

\section{MARINE RESEARCH AT ZANZIBAR}

\begin{abstract}
$\mathrm{N}$ important aspect of the International Indian Ocean A Expedition has been the part played by the various marine research stations in the area. Not only have they offered facilities for research vessels and made their own individual contributions to the Expedition, but, perhaps more important, their previous research activities have provided much valuable information on which the assault on the Indian Ocean could be planned. The research station at Zanzibar, although hampered during much of 1963 by the absence of its research vessel, R.V. Manihine (for refit and survey), nevertheless continued some promising lines of research and initiated some new ones*. Three new biologists were recruited during 1963, bringing the scientific complement up to four research officers in addition to the director.
\end{abstract}

In the absence of the R.V. Manihine, the deep longline investigation, work on demersal fishes, and hydrological work had to be abandoned. On the other hand, a new vessel, the 58. ft. Jodari, built by and for the use of the Government-sponsored Zanzibar Fisheries Development Co., Ltd., and the purchase of a $450 \times 45 \mathrm{fm}$. purse-seine net, enabled investigations to be made of day-time fishing for scombroid fishes. Of the latter, five types of shoal have been distinguished on their species composition, the majority of shoals containing honito and frigate mackerel in the proportions of $50: 50$ to $97: 3$. The food of the tuna examined consisted chiefly of small fishes (Stolephorus and Atherina) with occasional small crustaceans and cephalopods.

Two further boats were operated by the Zanzibar Fisheries Development Co. (39 ft. and $55 \mathrm{ft}$.), both used

* East African Common Services Organization. Annual Report of the East African Marine Fisheries Research Organization for 1963. Pp. iv +19 . in night purse-seining for sardine-like fishes. As elsewhere, night fishing with lights was limited to about twenty days between full moons. Initial difficulties were encountered in finding areas free from coral. Of the clupeid species, Sardinella jussieu (Lacépède), S. perforata (Cantor) and S. sirm (Walbaum) (the latter an offshore species) were the most abundant, but several small carangids were commonly caught (for example, Decapterus dayi Wakiya). The purse-seines also took significant numbers of tuna-like fishes. Highest landings were recorded during the periods May-July and November-. December.

Prawns collected during three cruises off the Tanganyika coast, supplemented by specimens from elsewhere in the Indo-Pacific Ocean, were reported on at the meeting of carcinologists at Zanzibar, organized by the Scientific Council of the Commission for Technical Co-operation in Africa South of the Sahara in April. Three useful papers on plankton were published during 1963, resulting from collections made in the Zanzibar area during 1960-61; one strongly denies the popular conception of the 'impoverishment of tropical seas'.

Interest in the work of the Zanzibar station is evidenced by the amount of financial assistance received from outside sources: Unesco for library material; the Rockefeller Foundation for hydrological equipment; the Food and Agriculture Organization for deep long-line gear; the Freedom from Hunger Campaign for purse-seine net; the Munitalp Foundation for hydrographic winch, etc. It is to be hoped that the valuable contributions made by Zanzibar to knowledge of the Indian Ocean and its fisheries will continue to be recognized.

P. J. P. Whitehead 